\title{
SHORTAGE OF MATHEMATICS TEACHERS IN BRITAIN
}

\begin{abstract}
A QUESTION was asked by Lord Boothby in the House of Lords as to whether, having regard to the essential part played by school mathematics in the training of scientists and technologists, and in view of the present shortage of more than 3,000 mathematical teachers in British schools and the fact that replacements were not matching retirements, the Government now proposes to take action to avert the incipient disintegration of technological training in Britain.
\end{abstract}

In replying on June 7, Lord Hailsham said that the Government has already taken action to meet the serious shortage of mathematics teachers in the schools, which it recognizes to be a matter of serious concern. He did not accept Lord Boothby's conclusion. The grave shortage of mathematics graduates able and willing to teach has been made known to the university authorities, and consultations are taking place with them about how the problem could best be tackled. The Minister of Education has also taken measures to improve the supply of nongraduate teachers of this subject.

Lord Boothby then referred to action taken by the National Science Foundation in the United States, of which full details had been given to Lord Hailsham, and to the recommendations of the Mathematics Conference at Southampton last April; but Lord Hailsham insisted that the core of the problem is the provision of graduates and that this is the province of the universities. As regards nongraduate teachers, the provision of a three-year as distinct from a two-year course has enabled the Minister of Education to raise the standard in teacher-training colleges. Lord Hailsham promised to note Lord Boothby's suggestion about better co-ordination between the Ministry of Education, his own Ministry, the University Grants Committee and the universities. He believes that there are difficulties in Baroness Summerskill's suggestion of a special financial premium for those teaching science and mathematics, and in reply to Lord Alexander of Hillsborough said that the anxiety of parents in relation to the present teaching of mathematics is not well founded. One factor in the shortage is the whole range of new opportunities now open to mathematics graduates. What is really wanted is an increase in the total output of graduates, and he is not satisfied we have as yet exhausted the potentialities of mathematical ability. He said that personally he is not satisfied that the methods of teaching mathematics could not be improved, so as to attract some who had hitherto been repelled. He thought that the shortage of mathematics teachers is likely to become, and is already, very much worse than the general shortage of teachers.

In a written answer in the House of Commons on June 13, the Minister of Education said that as a result of his Department's request to training colleges to give greater prominence to mathematics, the annual number of students reading mathematics as a main subject has risen from 770 in 1955-56 to 1,650 in 1960-61. The three-year course should greatly help to raise academic standards, and the colleges should then be sending forward to the primary and secondary schools more and better teachers of mathematics. He expected the numbers to rise further with the expansion of the colleges. The colleges are also providing one-year courses for substantial numbers of serving teachers, and various other shorter courses are also available for serving teachers and members of mathematics staffs in the training colleges. Advanced courses in the technical colleges leading to a degree or diploma in technology are also being expanded. The main problem is the shortage of mathematics graduates, particularly those able and willing to teach. Mathematicians in schools and universities had been actively discussing the question and canvassing possible solutions. He said he has made sure that the gravity of the shortage and the need for action are known to the university authorities. His Department has been working for some months with the Teachers' Advisory Council, and the universities have been approached through the Vice-Chancellors' Committee. It is proposed to hold a conference at an early date under university auspices to examine the evidence collected and consider possible action, and Sir David promised to bear in mind the suggestion of a White Paper.

It might be noted here that in the House of Commons on June 8, in replying to a question about difficulties anticipated in recruiting scientific staff for the universities expansion programme, Sir Edward Boyle said that the increase in recent years of the number of Department of Scientific and Industrial Research postgraduate training grants-from 979 in 1958 to 1,259 in October 1960 -would contribute materially to the supply of potential teachers. Besides considering representations about a further salary revision, the University Grants Committee is at present giving particular attention to the provision of adequate facilities for university staff, both for teaching and research (see also p. 103 of this issue).

\section{THE WELSH COLLEGE OF ADVANCED TECHNOLOGY}

\author{
By Dr. A. HARVEY \\ Principal of the College
}

\begin{abstract}
$A^{1}$ N additional building for the Welsh College of Advanced Technology, situated in Cathays Park, Cardiff, was formally opened by H.R.H. The Duke of Edinburgh on June 2, the ceremony forming part of the Welsh programme for Commonwealth Technical Training Week. The building re-houses the three Departments of Chemistry and Biology,
\end{abstract}

Navigation and Pharmacy. It also provides much improved amenities for the College as a whole, including a refectory, great hall, senior common room and a self-contained Students' Union suite.

The architect was Sir Percy Thomas, who was also (in conjunction with Mr. Ivor Bishop) responsible for the main building of the College, which was com- 